\title{
DISCOURSE-SHIFTING PRACTICES OF A TEACHER AND LEARNING FACILITATOR IN A BILINGUAL MATHEMATICS CLASSROOM
}

\author{
Robyn Tyler \\ University of Cape Town
}

In bilingual classrooms, content is often learned simultaneously with a new language. Recent applied linguistics research has identified shifts in discourse made by teachers and learners as they work towards these two goals. Departing from a sociocultural perspective on teaching and learning, this study assumes learners and teachers bring rich and diverse linguistic repertoires to the classroom. This paper examines selected episodes of discourse shifts which took place in a week-long mathematics enrichment programme run by a non-government organisation in rural South Africa. In this Xhosa-English bilingual context, I undertook a small-scale ethnographically-informed case study in which evidence of and comment on discourse shifting was collected in the form of video and audio recordings of lessons and interviews with participants. The focus of the analysis is on the translanguaging strategies (especially register meshing) of the teacher and a learning facilitator as they work to make the curriculum accessible to the learners. The argument made in the paper is that the unidirectional notion of discourse shifting from more everyday, spoken, home language discourses to more discipline-specific, written, English discourses is not adequate in explaining the complex multidirectional shifting apparent in my data.

Key words: translanguaging, learning facilitator, bilingualism, classroom discourse, language learning, register

\section{INTRODUCTION}

Studies of classroom discourse in bilingual contexts have revealed a rich tapestry of practices as classroom participants draw upon their various language resources to function as learners and teachers of a particular subject (cf. García \& Sylvan, 2011; Hornberger \& Link, 2012; Makalela, 2015; Probyn, 2015). Some of these practices are sanctioned by language-ineducation policy and education authorities; some are illicit (Mazak \& Herbas-Donoso, 2014; Probyn et al., 2002). The main study from which the present data are drawn examines the discursive practices of a teacher, learning facilitator and learners in a rural secondary Mathematics revision programme in South Africa as they enlist available language resources in the pursuit of learning and teaching Mathematics. The programme was run in 2011 by Focus Education ${ }^{1}$ in the Wild Coast region of the rural Eastern Cape, and employed a Mathematics teacher and a learning facilitator to present revision lessons to a select group of relatively highperforming Grade 11 learners from local schools. Educational non-governmental organisations (NGOs) in South Africa provide important support services to the government's Department of Basic Education which has inherited the enormous task of redressing the vast inequalities in the system post-Apartheid. NGOs lobby the government for change, provide additional resources to under-resourced schools, build or improve facilities such as libraries, provide staff training and support, offer extra-curricular or enrichment learning opportunities and support 
the curriculum. It is this last function which the Focus lessons were fulfilling, while they had other programmes which offered extra-curricular learning opportunities.

The linguistic and cultural composition of the Focus classroom was unusual in a South African educational setting in ways which are be elaborated on in the next section. Thus, it presented itself as an interesting case in which to investigate classroom language practices. The data show the presence of different discourses and modes in the bilingual classroom and that the teacher and the learning facilitator shifted between discourses to access the Mathematics curriculum, which is conceptualised as translanguaging (Garcia \& Li Wei, 2014; Makalela, 2014). This shifting is contrasted with other notions of how classroom participants move between discourses (Gibbons, 2006; cf. Setati \& Adler, 2000) in accessing the curriculum in order to critique these. I conclude by briefly outlining my recommendations for teaching and research based on this case study: to prioritise the role of a learning facilitator, especially in contexts where the teacher does not share the linguistic resources of the learners; to set as a research agenda understanding more fully the translanguaging practices of teachers and learners in classrooms in order to enhance these for curriculum access; and to foreground in teacher education the variety of discourses and methodologies such as translanguaging available to classroom teachers to facilitate learning.

\section{LANGUAGE CONTEXT}

The Focus classroom is described as bilingual due to the language competencies of its members and the intentional use of two named languages by the staff, namely, Xhosa and English. The teacher was an English-speaking, white South African who used a small repertoire of Xhosa phrases in her teaching for the three functions of code-switching in post-colonial classrooms described by Ferguson (2003): classroom management, interpersonal and curriculum. The learning facilitator was a Xhosa-English bilingual black South African first-year university student. Both the teacher and the learning facilitator grew up in the major urban centres of South Africa: Johannesburg and Cape Town respectively. The learners were Xhosa-speaking with a small repertoire of English used in interpersonal communication with the teacher and, when speaking about mathematical concepts, with the whole class. The learning facilitator functions as a bridge between the divergent life worlds of the teacher (urban, English-speaking) and the learners (rural, Xhosa-speaking). The 1997 Language in Education Policy (Department of Education, 1997: 1) positions these learners' home language as the bedrock of their learning: 'the underlying principle is to maintain home language(s) while providing access to and the effective acquisition of additional language(s)'. Ideally, the policy would have these learners using Xhosa as a core language in their learning of Mathematics while simultaneously enabling them to acquire English. This model of additive bilingualism is an unrealistic dream in their local schools where English is valorised above their home language, but unattainable. The highstakes exit examination from high school is offered in only English and Afrikaans, and English is dominant in tertiary education and the job market. In addition, teachers are not well trained in multilingual education (Setati, Adler, Reed, \& Bapoo, 2002) and the use of the learners' home language is often seen as a necessary evil (Probyn, 2009) with their goal being to use as little 'vernacular' as possible. Learners are challenged in learning through a foreign language by a low English language infrastructure (Setati et al., 2002) in their rural setting, which includes limited availability of television in English and some radio and print advertisements. All everyday activities are conducted using Xhosa. Hence, the intervention by Focus Education of employing a bilingual learning facilitator is key to successful teaching and learning, especially while the teacher acquires greater proficiency in Xhosa. The staff of Focus Education have an enabling attitude towards the use of different languages, although this is 
somewhat tempered by the high status of English in society (Phillipson, 2009), which results in the acquisition of English being privileged above the use of learners' home language for learning. In effect, these rural learners are like many South African learners whose home language is not the dominant language, English: they leave school with insufficient access to the language of power and an inflated sense of its importance (Janks, 2004).

The Focus Education director described in an interview how the mismatch between the language of the learners and the language of the curriculum and the teachers was a problem for their programmes: 'there is (a gap) between us, the teachers and the kids, yes with language but also with relating' (Focus Education director interview, 14/07/11)

As an English-speaker, the Mathematics teacher was well-versed in the language of the curriculum, but making that accessible to her Xhosa-speaking learners was a formidable challenge. As part of the response to this challenge, Focus Education enlisted the help of a learning facilitator to support the predominantly English teaching by using Xhosa and listening to the learners express ideas in Xhosa. This role was not defined but 'evolved quite naturally' (Focus Education director interview, 14/07/11), with the learning facilitator supporting the teacher where he saw fit. Lessons were planned by the teacher only, although she recognised that planning together could be helpful. The learning facilitator was able to form a bridge between the teacher and the learners and at times could mediate where understanding faltered between them. An additional function of the learning facilitator was to create a non-threatening, familiar environment in which the lessons could take place in a similar way to a cultural broker: a young person from the same cultural community as the learner who, through his/her relationship with the learner, draws the cultural worlds of the school and the home closer together (Gentemann et al., 1983).

\section{THEORETICAL FRAMEWORK}

\section{Conceptions of language in classrooms}

The study proceeds from a sociocultural view of language and learning. In opposition to a traditional cognitive view of learning which asserts that learning occurs within the individual mind, Vygotsky (1978) asserts that individual thought has a social origin: children's thinking stems from the social processes that they experience and they retain the functions of these social processes, which become internalised and construct the resources for individual thinking. These resources, or 'tools', are the cultural practices and artefacts which enable thinking and communication about thinking. The most important tool for thought and social activity is language. For Vygotsky, then, language mediates these two key human functions. Mercer (1995: 4) expresses the two functions as follows: 'Language is therefore not just a means by which individuals can formulate ideas and communicate them, it is also a means for people to think and learn together.'

The data analysis in this study followed features of sociocultural discourse analysis where there is a concern with the lexical content and the cohesive structure of the talk as these features of discourse can represent ways that knowledge is being jointly constructed (Mercer, 2004). The discourse available in the form of talk comprised the majority of my data, with written and other modes of language being viewed secondarily in terms of their relationship to the talk. The following claims have been made about the importance of spoken language in learning and have focused my analysis on spoken registers in my data. Barnes claims that spoken discourse is a useful tool for learning in that it is flexible and collaborative (Barnes, 1992). 
Wells (1992: 291) asserts that spoken discourse is an opportunity for learners to 'talk their way in' to ways of making sense of new information. In research on Mathematics teaching, Brodie has shown how teachers can work with learners' mathematical reasoning as it becomes available through talk (Brodie, 2010).

Having established that language is a tool for communicating and learning, it is the task of the classroom discourse researcher to conceptualise this tool in all its many instantiations. Following Fairclough (1992), I use the term 'discourse' to describe both the textual products and the socially situated practices of the classroom. This view of discourse as 'language-inuse' is concerned with the semiotic devices that are used as tools for interaction, for example: utterances, prosody, gestures, pictures, and the use of artefacts and objects (Bloome et al., 2005). These devices form the fabric of the socially situated practices which produce the textual products of the classroom. A view of language as practice emphasises the situated nature of all language use in which linguistic resources are drawn upon spontaneously in order to make meaning in the moment (Blommaert \& Backus, 2011; Heller, 2007). One of the purposes of this paper is to illuminate the different discourses which are used by all classroom participants in the joint construction of mathematical meaning (Barnes, 1992; Edwards \& Mercer, 1987; Mercer \& Littleton, 2007; Mercer, 1995). I have named different discourses (such as 'Mathematical English', introduced below) in the analysis somewhat uncomfortably given my concurrence with the recent rejection of the notion that named languages are discrete, stable, bounded entities (Blommaert \& Backus, 2011; Creese \& Blackledge, 2010; Makoe \& McKinney, 2014). However, the identification of spoken registers, particularly, which are employed in the classroom, sheds light on how participants are using language for learning and how successfully. Pimm (1987), writing about language issues in teaching and learning mathematics, identifies two spoken registers in mathematics classrooms. He argues that the 'mathematics register' or 'Mathematical English' (ME) is distinct from everyday language usage or Ordinary English (OE) in many respects, one being the differences in meanings of words. This is problematic because 'the alteration in meaning is less apparent' than when a coined specialist term is employed (Pimm, 1987: 79). When one word has different meanings in two different registers, learners are at risk of at best incomplete conceptual development, or at worst developing an inaccurate concept. For example, 'mathematicians tend to use any to mean "every", and, on occasion, their meaning conflicts with ordinary usage' (Pimm, 1987: 79 , italics in original).

The complexity of the interaction between discourses increases in bilingual classrooms as there is more than one named language present as an additional resource for learning. This study proceeds from a language-as-resource perspective (Genishi \& Dyson, 2009; Lo Bianco, 1996; Stein, 2000), which conceives of individuals and communities as embodying linguistic repertoires (Blommaert \& Backus, 2011; Busch, 2010) from which utterances are constructed. Within an EAL learning context, this enables the researcher to replace a deficit view of speakers, where the focus is on the linguistic resources that learners lack, with a competency view where linguistic repertoires that learners do have are acknowledged as resources for learning. Second Language Acquisition theory has extolled the benefits of the use of different discourses in named languages and in other modalities such as gesture to scaffold learning (Bruner, 1966). Jewitt et al. (2001) describe how multimodality in science classrooms aids language learning. Wong-Fillmore (1985) describes the presentation of materials in different ways in the classroom such as talk, board work and demonstration as 'message redundancy' and Gibbons (2006) builds on Wong-Fillmore's notion by including further semiotic systems such as graphs, mathematical systems and images. She uses the term 'message abundancy' to describe a pedagogical practice which includes mode shifting in spoken language as well as 
across other semiotic systems. This provides the learners with different access points to the material and more than one chance to make meaning. Message abundancy can be created through the enactment of different languages, registers and subject positions in the classroom. This links to the concept of heteroglossia (Bakhtin, 1981) or 'many voices', which asserts that, in every instance of language use, diverse linguistic resources are being used simultaneously in meaning-making, including the two named languages in the bilingual Focus classroom.

The 'many voices' of the Focus classroom are given expression in the service of learning Mathematics. I now turn to the mechanics of how the different discourses are used. In contrast to traditional conceptions of code-switching (such as Ferguson, 2003, cited above), which limits the object of study to natural languages within firm boundaries, applied linguists working with the view of language as resource have recently taken up the term 'translanguaging' to describe how language users employ their linguistic resources in the service of learning. While 'translanguaging' initially referred to a particular EAL methodology described by Williams (cited in Baker, 2006), it has been elaborated to describe what bilinguals do as they employ linguistic features of different named languages as well as other communicative modes, such as gesture, in classrooms and other contexts (Canagarajah, 2011; Creese \& Blackledge, 2010; Garcia, 2009; García \& Sylvan, 2011; Hornberger \& Link, 2012). While Garcia and Li Wei (2014) emphasise that translanguaging is the natural activity of a bilingual individual who draws upon different elements of their linguistic repertoire when using language, Makalela $(2014,2015)$ helps us to see how in an African context it also refers to how pre-colonial African societies functioned in the use of his term 'ubuntu translanguaging' (Makalela, 2014, 2015). Ubuntu translanguaging refers to the fluid movement between languages which characterises African multilingualism denoting the interdependence of people in Africa (Makalela, 2015). Makalela also refers to the facilitation of 'fluid identity construction' which ubuntu translanguaging enables (Makalela, 2014). Using the theoretical lens of translanguaging, the Focus classroom becomes a stage for the fluid use of linguistic resources within and between individuals towards the goal of learning Mathematics. The notion of fluidity is particularly salient in this data as the discourse-shifting which occurs will be shown to be multidirectional.

\section{The sequencing principle}

Theorists have previously argued that learning follows a sequencing principle (Halliday, 1975) from experiential to expository learning (Gibbons, 2006) and therefore that learning discourse is sequenced from implicit to explicit and practical to theoretical (Mohan, 1986). Language-ineducation researchers have taken up this unidirectional approach to the development of registers in learning and have asserted that not only is this ubiquitous, but it is also appropriate for learning. Two studies demonstrate this unidirectional approach. In her study of an EAL science classroom in Australia, Gibbons (2006) focuses on the bridging discourses of the teacher which she defines as, 'the process of teacher-student interaction' (Gibbons, 2006: 1, italics in original) in which their talk draws together 'everyday' language and the academic registers of the school. She uses the notion of a mode continuum (Derewianka, 1990; Martin, 1984), which positions spoken language and written language at opposite ends of the continuum, to describe how 'the discourse in the two classrooms moved from situationallyembedded talk towards the more formal and public discourse of school science' (Gibbons, 2006: 168). In the South African context, Setati and Adler (2000) extend this 'one-way' movement when examining multilingual classrooms to assert that not only does the discourse move from more spoken-like to more written-like registers and from 'everyday language' to 'discourse-specific language', but that it moves from the home language of the learners to the language of learning and teaching. The present data show how a unidirectional notion of 
discourse shifting oversimplifies the ways in which different discourses are used in bilingual classrooms and I assert that the shifting is in fact multidirectional (cf. García \& Sylvan, 2011). This kind of shifting is aligned with ubuntu translanguaging in that it is flexible and fuzzy, but logical (Makalela, 2014). It also allows connections to be reinforced between learners' out-ofschool and in-school lives, a task for which the Focus learning facilitator was well-positioned.

\section{METHODOLOGY}

This study was an ethnographically-informed small-scale case study. The bounded phenomenon (Knobel \& Lankshear, 1999) about which I collected data was the use of discourse in a week-long mathematics enrichment programme. I joined the Grade 11 Mathematics classes as a non-participant observer for the five hour-long lessons, taking fieldnotes and video- and audio-recording. I obtained consent from all participants directly in writing as they were all above the age of 16. I remained at the back of the classroom with the video-recorder fixed on a tripod, occasionally zooming or panning following my interest. At the beginning of each period, I handed an audio recorder to both the teacher and the learning facilitator, who wore these on lanyards around their necks. I interacted socially with all participants briefly before and after the lesson, and the learners took a keen interest in my recording equipment, on two occasions performing in front of the camera. There was a possible unobservable increase in anxiety about producing spoken discourse for the participants given the presence of myself and the recording equipment, but this could not be verified and was not commented on in interviews. Instead, I sought to allay fears by introducing my study comprehensively to all participants and positioning myself as a Xhosa learner and the learners as experts in order to reduce the power differential that existed between us. I interviewed three learners (assisted by a bilingual Xhosa-English interviewer), the teacher, the learning facilitator and the Focus Education director in order to probe the discursive practices.

In my analysis I first described the discursive space of the Focus classroom, then identified categories of bridging discourses and inserted examples into the categories while allowing the examples to refine the categories. I identified five broad bridging discourses and named them: Xhosa-for-Mathematics, message abundancy, uptake of learner contributions, talk about language and unpacking written ME. In the discussion of data which follows, Extracts 1, 2 and 4 have been drawn from the message abundancy category and Extract 3 is taken from a learner interview.

\section{THE DATA}

\section{Shifts between discourses}

The mathematical topic for the lesson series was 'Transformations', where mathematical objects are transformed on the Cartesian plane. ${ }^{2}$ The first lesson opened with a teacher-led discussion of the concept of 'transformation'. An extract from the transcript of that lesson, reproduced below, illustrates the abundance of discourses present in the classroom.

\section{Extract 1}

(1) T: (gesturing towards the blackboard where the word 'Transformations' has been inscribed with reverse orthography and with some letters rotated, enlarged or otherwise transformed from their usual shape) What have I done differently up there?

(2) L1: (twists wrists in a turning gesture) 
(3) T: Someone's doing this to me (copies the gesture of the learner). What's the word for this (continues copying the gesture)?

(4) L1: Reflection.

(5) T: Ja. Okay. So, um, Ezekial says reflection. Okay, so the first thing. I've done lots of different things to this but the first thing is that I've taken my word and I've flipped it, okay I've reflected it. Okay. So this whole thing has been (writing 'reflected' on the board) ja, re..flected. Okay? Flipped.

(6) T: (To LF) What was the word that you said?

(7) LF: Guquka (turn over/turn around). (spells out the word while T transcribes it onto the blackboard) G.U...K.A, guquka.

Six discourses have been identified in this extract and the shifts that the classroom participants make between the discourses have been arranged into columns, below, with $\mathrm{T}=$ teacher, $\mathrm{L}=$ learner and $\mathrm{LF}=$ learning facilitator:

Table 1: Shifts between discourses in Extract 1

\begin{tabular}{|l|l|l|l|l|l|l|}
\hline $\begin{array}{l}\text { Discourse } \\
\rightarrow \\
\text { Turn } \\
\downarrow\end{array}$ & $\begin{array}{l}\text { Graphic } \\
\text { metaphor }\end{array}$ & Gesture & $\begin{array}{l}\text { Spoken } \\
\text { Ordinary } \\
\text { English } \\
\text { (OE) }\end{array}$ & $\begin{array}{l}\text { Spoken } \\
\text { Ordinary } \\
\text { Xhosa }\end{array}$ & $\begin{array}{l}\text { Spoken } \\
\text { Mathematical } \\
\text { English } \\
\text { (ME) }\end{array}$ & $\begin{array}{l}\text { Written } \\
\text { Ordinary } \\
\text { Xhosa }\end{array}$ \\
\hline 1 & T & & T & & & \\
\hline 2 & & L & & & & \\
\hline 3 & & T & T & & & \\
\hline 4 & & & & & L & \\
\hline 5 & & & T & & T & \\
\hline 6 & & & T & & & T \\
\hline 7 & & & & LF & & \\
\hline
\end{tabular}

The table shows the distribution of six different discourses across seven speaking turns and across three speaking parties. In four turns, more than one discourse is used to express a concept. Therefore, the shifting is abundant both within a turn and between turns. The teacher, as the leader of the discourse, inscribes a graphic metaphor and ordinary Xhosa onto the blackboard, shifts between the registers of ME and OE in her speech, and draws on a learner's use of gesture and the learning facilitator's knowledge of ordinary Xhosa. Later, the discourse of written mathematical symbols is added to the classroom repertoire. Abundance of discourses is important for language learning (Gibbons, 2006), as this provides multiple pathways to meaning-making for the EAL learner. What the table above also graphically demonstrates is that the shifting between discourses is multidirectional. The participants move back-and-forth between the discourses and do not end with the target register of ME, as would be expected if following the sequencing principle of discourse in learning (Halliday, 1975). The implications for learning of the abundance and multidirectionality of the discourse shifting are revealed through a turn-by-turn analysis of the extract.

The teacher begins by inscribing a conceptual puzzle onto the blackboard. The message is immediately multimodal in its presentation and the invitation to consider the mathematical concepts comes in the form of an open question posed in 'everyday' language, or OE: 'What have I done differently up there?'. The use of unconventional writing and accessible spoken language by the teacher models exploratory thinking and talk as a way in to the new topic. The use of these informal modes also opens the possibility of learners responding in non-academic 
modes. A learner responds to her question (2) through the discourse of gesture - a nonthreatening, flexible discourse (Jewitt \& Kress, 2003). The teacher then provides a press on the learner's linguistic resources (3) (Gibbons, 2006) so that he is able to produce the ME term 'reflection'(4). The teacher accepts and validates his response by echoing it (5). From this point, the teacher moves back to OE to provide the metaphor of 'flipping' a letter in order to deepen the learners' understanding of the concept of reflection. Verbal and physical metaphors abound in this lesson series, which is typical of Mathematics teaching (Pimm, 1987). In OE 'flip', 'reflect' (as in a mirror) and 'fold'; the description of mud being transferred to the opposite side of a page which has been folded; and in Xhosa '-songa' (fold) and '-goba' (fold) are all used as metaphors for the concept of reflection. Physical metaphors used by the teacher and learning facilitator during the lesson series are: a gesture where the hands are opened and closed to simulate a fold, a gesture where the wrists are rotated to simulate turning, burning a hole through a folded piece of paper to simulate an identical shape on opposite sides of the sheet and the folding of a scarf. Pimm (1987: 97) argues for the merits of using metaphor in mathematics teaching as follows:

(Images allow pupils to discover the) rich inner mental realms in which mathematics properly takes place... Whether or not a particular offered image is successful in illuminating a concept, it at least serves the purpose of indicating that image-making is an appropriate activity for pupils to be engaged in, and that the teacher has personal images of the mathematics in question.

Further discussion of the use of metaphor follows in the next data section.

In (5), the teacher uses the OE and ME terms 'flip' and 'reflect' in quick succession in order to indicate that these forms can be substituted when dealing with one mathematical concept. Gibbons calls this kind of seamless shifting between discourses 'register-meshing' (Gibbons, 2006: 131). She argues that this achieves comprehensible input for EAL learners while at the same time modelling new language. This register-meshing is characteristic of the teacher's spoken discourse and serves to trouble the binary of 'everyday' and scientific language described by Setati et al. (2002). These registers do not operate in silos in this classroom. The learners in this class, however, may not be sufficiently comfortable with the OE term 'flipped' to make the input comprehensible. I contend that, by incorporating the discourse of gesture, as the teacher does, she adds another quiver to her bow in her quest to make the content comprehensible.

The teacher ends by incorporating the Xhosa term 'guquka' (turn over/turn around) $(6,7)$, which was used by the learning facilitator in an earlier lesson as another expression of the same concept, giving written ordinary Xhosa authority in the classroom. A brief discussion of the meaning of this word sheds lights on how Xhosa words are used in the classroom in a similar way to $\mathrm{OE}$ words, that is, as metaphors for the mathematical concept being taught. As indicated, the word '-guquka' means 'turn, come back; change form or place' (Tshabe \& Shoba, 2006). The second of these meanings is general enough to be applied to any of the four sub-topics of Transformations. However, when I interviewed two Xhosa speakers known to me about the use of '-guquka', they both argued that it is used to talk about someone turning over in bed, or turning back from their path to walk in the opposite direction. Also, another word was used later in the lessons in reference to the concept of reflection: 'guqula', which means 'turn something over to face in another direction; turn over' (Tshabe \& Shoba, 2006). These meanings are equivalent to the OE words 'turn' or 'flip', which are used as metaphors by the teacher for the mathematical concepts of reflection. Terms used in the mathematical topic 
'Transformation' appear in a textbook developed by multilingual teachers to promote understanding of key mathematical and scientific concepts in English, Xhosa, Zulu and Afrikaans. The translation and explanation of the concept of transformation in Xhosa is as follows:

Uguqu-guqulo: ukuguqu-guqula isazobe kukuguqula ubungakanani baso, ukutshintsha indawo okanye ukujongeka kwaso ungatshintshanga kumila kwaso. (Transformation: Transforming a figure is changing its size, location or orientation without changing its shape.) (Young, Van der Vlucht \& Qanya, 2005: 45)

In the note on reflection, the translation of 'reflection' is given as 'isazobe-sithunzi', next to which appears a picture of two birds facing one another, the one a mirror-image of the other. Next to this is a further English explanation of reflection: 'Producing a mirror image of the figure. This is also called flipping the figure' (Young et al., 2005: 45). The Xhosa translation of 'reflection' is not used in the Focus classroom, but rather the more general term 'guqula', which more closely approximates 'transform' than 'reflect'. This could cause confusion for the learners and makes a case for further negotiation of the terms used in the lessons (cf. Paxton \& Tyam, 2010). Indeed, in one instance a learner confused the terms 'transformation' and 'translation' and was corrected by the teacher.

By incorporating - and in the case of the learning facilitator, inscribing - the diverse discursive resources of the learners and the learning facilitator, the teacher is valorising them, as she holds the most authority in the classroom by virtue of her position as teacher. Her message is that these discourses are appropriate for learning Mathematics. In this extract, the learners are taciturn, which is a feature of the lesson series as a whole, with one notable exception where a learner reasoned through a problem publically and asked a peer for help. Therefore, their opportunities for working on comprehensible output and 'talking their way in' to the discipline was limited.

\section{Use of multimodality}

Physical metaphors used by the teacher and learning facilitator have been described above. The use of gesture and apparatus to construct these metaphors by the learning facilitator is the focus of this section. In the following extract, the learning facilitator is working with the mathematical procedure of reflection through folding his scarf:

\section{Extract 2}

(1) Nithi ndiza'sisonga su, sibenje, sibengake. Ndiphinde ndithini? (You're saying I must fold it like this so that it can look like that - that it's this size. Then, what must I do next?)

(2) Ls: 'Songe (Fold it.)

(3) LF: N'phinde ndisisonge. (I must fold it again.) Now, ndiza'- ndiza'uya njani ngapha, nithini ndisuke ku-one, ndiye ku-four- (Now, how will I - how will I get there? You're saying I go from one to four.)

(4) L: Uyagqitha (You pass that.) 
(5) LF: (folding the scarf erroneously) Ndiphinde ndiye ngapha? (Then I go over there?)

(6) Ls: (while laughing) //Hawu// (no)// eh// //okay//

(7) LF: Niyayibona? (Do you see?)

(8) Ls: Yes.

(9) LF: Ndizakwazi? (Will I be able to do this?)

(10) Ls: No.

(11) LF: 'Ndizukwazi. Ndisuka ngapha, ndiye ngapha (I can't do this, I've come from here, I'm going to here.)

There are a number of features of this discourse which makes it a rich point for learning. The use of gestural metaphor and an everyday object as learning apparatus makes the mathematical procedure feel more familiar to the learners and fulfils the function of 'image-making' (Pimm, 1987). The use of ordinary Xhosa as a common register for the learning facilitator and the learners immediately invites more participation from the learners. The positioning of the learners as instructors (1) and the learning facilitator as the error-maker (5) gives the learners agency in this interaction. The oral participation of the learners which this generates is unprecedented in the lesson series up to this point. This forms an important part of rapportbuilding between the learners and the learning facilitator which is evidenced by the relaxed laughter in (6).

Despite the enthusiastic involvement by all participants in the scarf demonstration, there is a feature of the scarf metaphor which is immediately confusing. In the concrete example, the scarf can be folded multiple times, but the procedure of ascertaining the position of a point on the Cartesian Place involves only one move. However, I hold that the benefits of investment in the lesson by the learners and the rapport built with the learning facilitator through clowning and laughter $(5,6)$ outweigh the possible conceptual difficulties with the metaphor. The clowning in the discourse of ordinary Xhosa and the use of an everyday object as learning apparatus make the joke very accessible to the learners, as evidenced by their prolific laughter. This serves as an emotional release for the learners who are engaged in the difficult task of learning mathematics. One learner (Thando) spoke of the usefulness of the learning facilitator's gesture (and perhaps use of apparatus as well) in his interview:

\section{Extract 3}

I: So, uyasebenza umzimba wakhe - (So, does he use his body -)

Thando: Usebenzisa umzimba wakhe ukucacisa. (He uses his body to explain.)

I: But iyanceda ukukhumbula. (But does it help you to remember?)

Thando: Ja, iyanceda. (Yes, it does.)

\section{(iii) Drawing attention to the language}

According to Gibbons (2006), an important pedagogical move in discourse shifting, especially between the registers of everyday and academic language, is drawing attention to the language being used. The different registers are pointed out, not to emphasise the correctness of one 
register and the incorrectness of another, but rather to emphasise and contextualise the new register which needs to be learned (Gibbons, 2006: 132). The Focus Education teacher draws attention to the register of ME in the following extract:

Extract 4

\author{
L: Shifted. \\ weird because translate we think of language. \\ LF: Mm. \\ T: Okay? But if it's translated it means it's shifted or it's moved.
}

T: It has shifted, okay? So, these two and my 's' they have shifted. They have moved. Or the fancy mathematical word, they have translated. Okay, this word's a little bit

The teacher draws attention to the different register into which she moves by referring to the word 'translated' as 'the fancy Mathematical word'. She also casts the word as problematic through the adjective 'weird' and provides a brief allusion to the OE meaning of 'translate' ('we think of language'). In this way, she empathises with any confusion her learners may experience with the terminology and makes the reason for this confusion explicit. The learning facilitator affirms her explanation and that the word may indeed cause confusion by his hum of agreement. The teacher then shifts back into the register of OE and uses two OE words for 'translated': 'shifted' and 'moved'. This forms her explanation of the meaning of the ME term. The proliferation of the tag question, 'okay?', in this extract highlights the teacher's estimation of the high cognitive demand of the new register on her learners. Her tag question fulfils the dual functions of checking for understanding and providing a pause in the presentation of new content. On another occasion, she asked the learners about the accuracy of her Xhosa use, hence her metalinguistic talk is supported by her identification as a language learner herself making the language an appropriate object of study in her classroom.

\title{
CONCLUSION
}

The discourses employed for learning in the data were drawn from a variety of semiotic modes and connections were made between them through translanguaging. The shifts between discourses observed in this study happened in a multidirectional way and not linearly as the theory of sequential learning sets up, and as Setati and Adler (2000) and to an extent Gibbons (2006) describe. The back-and-forth nature of this shifting, or translanguaging, gave the learners opportunities to make connections between registers for Mathematics as well as developing receptive ability in the new register of $\mathrm{ME}$ when this register was highlighted. In this lesson series, the teacher also drew attention to the different discourses. She made them explicit by using metalanguage and identifying herself as a language learner. As the leader of the discourse, her willingness to include different registers in the classroom was an important point of departure. It also facilitated learning through allowing the learner to identify with the content as their linguistic repertoires are valorised in the process. The learning facilitator formed a linguistic and relational bridge between the learners and the teacher/curriculum.

The findings have the following implications for human resources in education, further research and teacher education. Firstly, the role played by the learning facilitator was particularly valuable in this setting where there existed a significant gap between teacher/curriculum and learners; however, learning facilitators could be valuable in any multilingual education situation. Nathanson's (2014) suggestions for using pre-service teachers as resources in professional development schools could be taken up by having them work as learning facilitators alongside existing staff. Secondly, the finding indicating the 
multidirectional nature of the discourse-shifting in this classroom calls for further research. Further description of translanguaging practices of teachers and learners such as those in the present study to discover, for example, how ubiquitous the multidirectional switching described here is in multilingual classrooms and to test whether the affordances of this switching are similar in different contexts such as highly linguistically diverse urban classrooms. Lastly, in a multilingual country such as South Africa it is imperative for teachers to recognise the heteroglossic nature of the discursive practices of learners in their classrooms (Makoe \& McKinney, 2014) and to be able to draw on the diverse linguistic resources in pursuit of learning. In teacher education, the goal should be to enable teachers to develop a set of translanguaging competencies suited to their classroom's particular linguistic environment while gaining an understanding of how the use of a range of learners' linguistic resources positions them more strongly as capable learners. The kind of translanguaging strategies I recommend are flexible and inclusive of a variety of languages, modes and registers, aligned with the notion of ubuntu translanguaging (Makalela, 2015).

\section{END NOTES}

${ }^{1}$ All names of participants and the organisation have been changed to ensure anonymity.

${ }^{2}$ In this mathematical topic, Grade 11 s need to be able to perform four kinds of transformations on the Cartesian Plane: reflection (finding the co-ordinates of a mirror-image of the figure in an axis); rotation by $90^{\circ}$ or $180^{\circ}$ (the figure is 'turned' a specified number of degrees); translation (the figure is moved by a specified number of units on the plane) and enlargement (the figure is enlarged or reduced in area by a specified factor).

\section{TRANSCRIPTION CONVENTIONS}

\begin{tabular}{|l|l|}
\hline$\ldots$ & a pause, each dot indicating a second \\
\hline (inaudible) & the speech following is inaudible \\
\hline (moves forward) & $\begin{array}{l}\text { explanations of movement, gesture or expression are given in italics } \\
\text { and brackets }\end{array}$ \\
\hline (turn around) & English translations of Xhosa are given in brackets after the clause \\
\hline I & speech has been omitted, next relevant clause continues after the / \\
\hline L & learner \\
\hline L1 & specific learner \\
\hline Ls & More than one learner speaking simultaneously \\
\hline T & Teacher \\
\hline LF & Learning facilitator \\
\hline I & interviewer \\
\hline bold & speech in Xhosa \\
\hline$(1)$ & number given to a speaking turn in a long extract \\
\hline // & Overlapping speech \\
\hline
\end{tabular}

\section{ACKNOWLEDGEMENTS}

I would like to thank Carolyn McKinney, Margaret Probyn and the anonymous reviewers for their invaluable comments and guidance on this article. 


\section{REFERENCES}

BAKER, C. 2006. Foundations of bilingual education and bilingualism (4th ed.). Clevedon: Multilingual Matters.

BAKHTIN, MM. 1981. Discourse in the novel. In Holquist, M (Ed.). The dialogic imagination: Four essays. Austin, TX: University of Texas Press.

BARNES, D. 1992. The role of talk in learning. In Norman, K (Ed.). Thinking voices. London: Hodder and Stoughton. 123-128.

BLOMMAERT, J \& A BACKUS. 2011. Repertoires revisited: "Knowing language" in superdiversity. Working papers in Urban Language and Literacie: Paper 67.

BLOOME, D, SP CARTER, BM CHRISTIAN, S MADRID, S OTTO \& N SHUART-FARIS. 2005. Discourse analysis and the study of classroom language \& literacy events: A microethnographic perspective. New York: Teachers College Press.

BRODIE, K. 2010. Teaching Mathematical reasoning in secondary school classrooms. New York: Springer.

BRUNER, J. 1966. Towards a theory of instruction. Cambridge, MA: Belknap Press.

BUSCH, B. 2010. School language profiles: Valorizing linguistic resources in heteroglossic situations in South Africa. Language and Education, 24(4):283-294.

CANAGARAJAH, S. 2011. Translanguaging in the classroom: Emerging issues for research and pedagogy. Applied Linguistics Review, 1-28.

CREESE, A A \& BLACKLEDGE. 2010. Translanguaging in the bilingual classroom: A pedagogy for learning and teaching? The Modern Language Journal, 94(1):103-115.

DEPARTMENT OF EDUCATION. 1997. Language in Education Policy. Government Gazette, 17997(383). Pretoria: Department of Education.

DEREWIANKA, B. 1990. Exploring how texts work. Rozelle, NSW: Primary English Teaching Association.

EDWARDS, D \& N MERCER. 1987. Common knowledge: The development of understanding in the classroom. London: Routledge.

FAIRCLOUGH, N. 1992. Intertextuality in critical discourse analysis. Linguistics and Education, 4(3-4):292-293.

FERGUSON, G. 2003. Classroom code-switching in postcolonial contexts. AILA Review, (16):38-51.

GARCIA, O. 2009. Bilingual education in the 21 st century: Global perspectives. Malden, MA: Blackwell.

GARCIA, O \& LI WEI. 2014. Translanguaging: Language, bilingualism and education. Basingstoke: Palgrave Macmillan.

GARCÍA, O \& CE SYLVAN. 2011. Pedagogies and practices in multilingual classrooms: Singularities in pluralities. The Modern Language Journal, 95(3):385-400.

GENISHI, C \& AH DYSON. 2009. Children, language, and literacy: Diverse learners in diverse times. Washington, DC: Teachers College Press.

GENTEMANN, KM, TL WHITEHEAD \& CC HILL. 1983. The cultural broker concept in bicultural education. The Journal of Negro Education, 52(2), 118-129.

GIBBONS, P. 2006. Bridging discourses in the ESL classroom. London: Continuum.

HALLIDAY, MAK. 1975. Learning how to mean - explorations in the development of language. London: Edward Arnold.

HELLER, M. 2007. Bilingualism as ideology and practice. In Heller, M (Ed.), Bilingualism: A social approach. Basingstoke: Palgrave Macmillan. 1-24.

HORNBERGER, NH \& H LINK. 2012. Translanguaging and transnational literacies in multilingual classrooms: a biliteracy lens. International Journal of Bilingual Education and Bilingualism, 15(3):261-278. 
JANKS, H. 2004. The access paradox. English in Australia, (139):33-42.

JEWITT, C \& G KRESS. 2003. Introduction. In Jewitt, C \& G Kress (Eds.). Multimodal literacy. New York: Peter Lang.

JEWITT, C, G KRESS, J OGBORN \& C TSATSARELIS. 2001. Exploring learning through visual, actional and linguistic communication: The multimodal environment of a science classroom. Educational Review, 53(1):5-18.

KNOBEL, M \& C LANKSHEAR. 1999. Ways of knowing: researching literacy. Marrickville, NSW: Primary English Teaching Association.

LO BIANCO, J. 1996. Language as an economic resource. Pretoria: CTP Book Printers.

MAKALELA, L. 2015. Moving out of linguistic boxes: The effects of translanguaging strategies for multilingual classrooms. Per Linguam, 29(3):200-217.

MAKALELA, L. 2014. Fluid identity construction in language contact zones: Metacognitive reflections on Kasi-taal languaging practices. International Journal of Bilingual Education and Bilingualism, (October):1-15.

MAKOE, P \& C MCKINNEY. 2014. Linguistic ideologies in multilingual South African suburban schools. Journal of Multilingual and Multicultural Development, 35(7):658673.

MARTIN, J. 1984) Language, register and genre. In Christie, F (Ed.). Children writing, study guide. Hawthorne, Australia: ACER. 79-117.

MAZAK, CM \& C HERBAS-DONOSO. 2014. Translanguaging practices at a bilingual university: A case study of a science classroom. International Journal of Bilingual Education and Bilingualism, (December):1-17.

MERCER, N. 1995. The guided construction of knowledge: Talk amongst teachers and learners. Clevedon: Multilingual Matters.

MERCER, N. 2004. Sociocultural discourse analysis: Analysing classroom talk as a social mode of thinking. Journal of Applied Linguistics, 1:137-168.

MERCER, N \& K LITTLETON. 2007. Dialogue and the development of children's thinking: A sociocultural approach. London: Routledge.

MOHAN, B. 1986. Language and content. Reading, MA: Addison-Wesley.

NATHANSON, RR. 2014. A professional development school model for the development of literacy teachers. Per Linguam, 30(1):127-144.

PAXTON, M \& N TYAM. 2010. Xhosalising English? Negotiating meaning and identity in Economics. Southern African Linguistics and Applied Language Studies, 28(3):247-257.

PHILLIPSON, R. 2009. English in globalisation, a lingua franca or a lingua Frankensteinia? TESOL Quarterly, 43(2):335-339.

PIMM, D. 1987. Speaking mathematically: Communication in mathematics classrooms. London: Routledge.

PROBYN, M. 2009. 'Smuggling the vernacular into the classroom': Conflicts and tensions in classroom codeswitching in township/rural schools in South Africa. International Journal of Bilingual Education and Bilingualism, 12(2):123-136.

PROBYN, M. 2015. Pedagogical translanguaging: bridging discourses in South African science classrooms. Language and Education, 29(3):218-234.

PROBYN, M, S MURRAY, L BOTHA, P BOTYA, M BROOKS \& V WESTPHAL. 2002. Minding the gaps - an investigation into language policy and practice in four Eastern Cape districts. English, 20(1):29-46.

SETATI, M \& J ADLER. 2000. Between languages and discourses: Language practices in primary multilingual mathematics classrooms in South Africa. Educational Studies in Mathematics, 43:243-269.

SETATI, M, J ADLER, Y REED \& A BAPOO. 2002. Incomplete journeys: Code-switching and other language practices in Mathematics, Science and English Language classrooms 
in South Africa. Language and Education, 16(2):128-149.

STEIN, P. 2000. Rethinking resources: multimodal pedagogies in the ESL classroom. TESOL Quarterly, 34(2):333-336.

TSHABE, SL \& FM SHOBA. 2006. The greater dictionary of isiXhosa. Cape Town: University of Fort Hare.

VYGOTSKY, L. 1978. Mind in society: the development of higher psychological processes. Cambridge, MA: Harvard University Press.

WELLS, G. 1992. The centrality of talk in education. In Norman, K (Ed.). Thinking voices: The work of the National Oracy Project. London: Hodder and Stoughton.

WONG-FILLMORE, L. 1985. When does teacher talk work as input? In Gass, S \& C Madden (Eds.). Input in second language acquisition. Rowley, MA: Newbury House.

YOUNG, D, J VAN DER VLUGT \& S QANYA. 2005. Understanding concepts in Mathematics and Science: A multilingual learning and teaching resource book in English, isiXhosa, isiZulu and Afrikaans. Cape Town: Maskew Miller Longman.

\section{BIOGRAPHICAL NOTE}

Robyn Tyler is currently enrolled as a doctoral student in Language and Literacy Studies in the School of Education at the University of Cape Town. She is also a teacher educator. Her current research interests are: bilingual learning in the Science disciplines and translanguaging and identity in discourse appropriation. Email: robynltyler@gmail.com 